AML12 polyclonal cell lines from ATCC

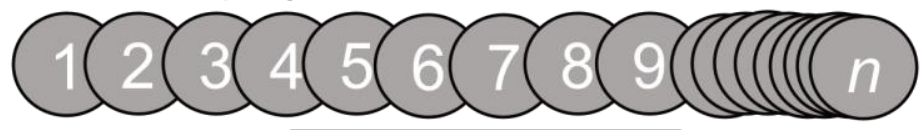

\title{
Cell Cloning
}

6

Selected monoclonal cell Line 6 as the parent line

\section{CRISPR/Cas9}

\section{FACS Sorting}

\section{Cell Cloning}

monoclonal CRISPR WT, heterozygous KO, or homozygous KO cell Lines

\section{Surveyor PCR}

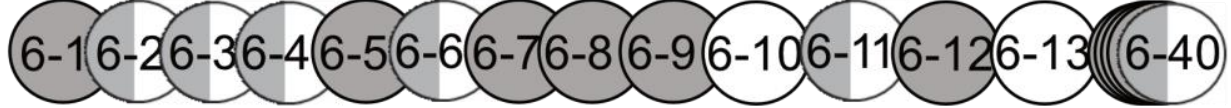

\section{Western/Mass Spec}

6-8 C-WT Control;

6-10 6-13) homozygous C-KO

Figure S1. Cell cloning strategy for CRISPR/Cas9 deletion of VWA8. Monoclonal parent cell line 6 was created by limiting dilution from stock polyclonal AML12 cells and was used to create CRISPR knockout (KO) and CRISPR wildtype (WT) control cells. CRISPR wildtype cells are cells that underwent the CRISPR/Cas9 process without successful deletion of VWA8. Subsequent analysis showed these cells to be equivalent to the parent cell line. Confirmation of deletion of VWA8 gene (Surveyor PCR) and protein (Western blot, mass spectrometry yielded CRISPR wildtype cell line 6-8 and CRISPR knockout cell lines 6-10 and 6-13. 


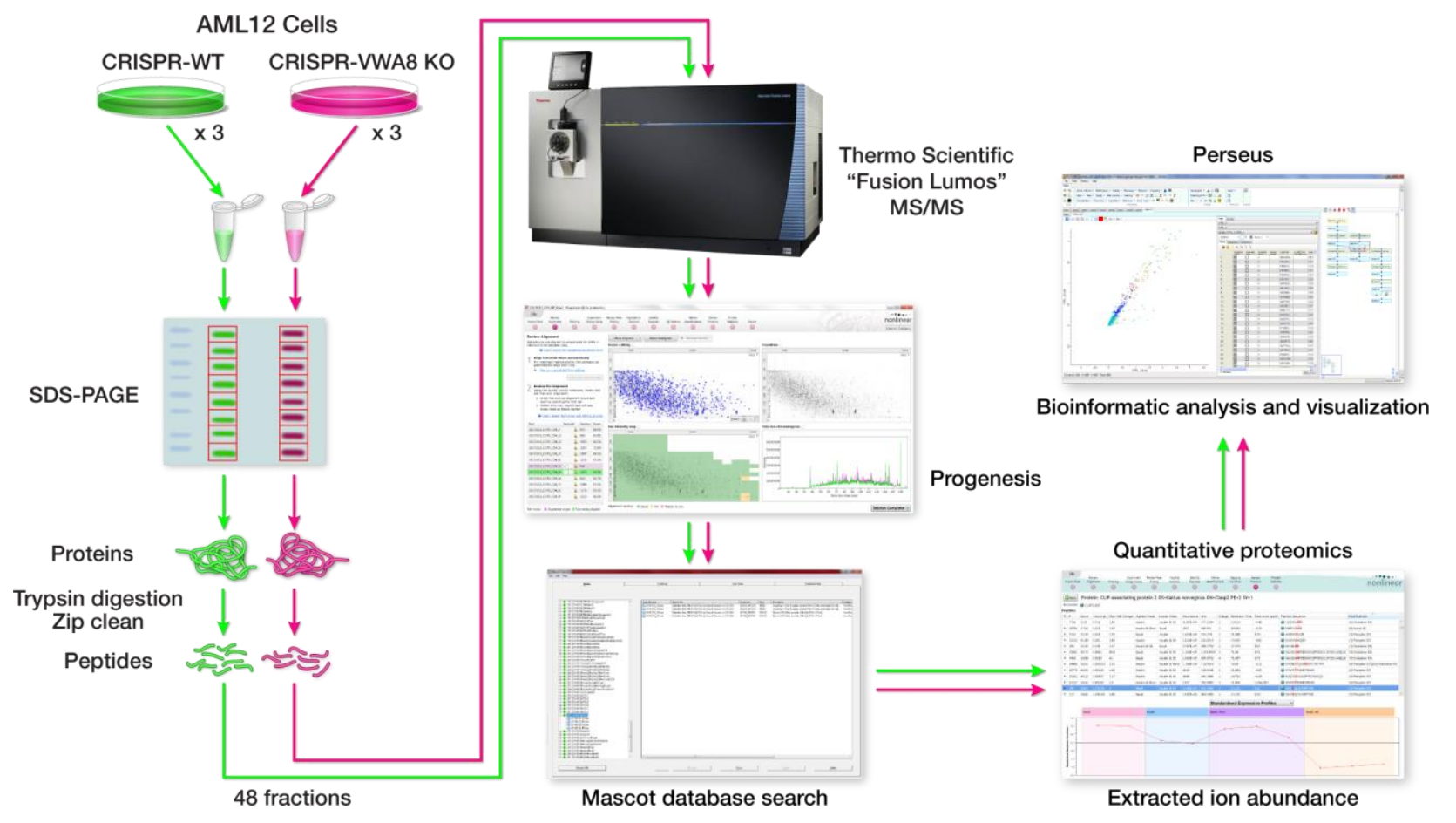

Figure S2. Proteomics workflow. 
Table S9. Comparison of Seahorse respiration results in differentiated, permeabilized wildtype and VWA8-null AML12 hepatocytes.

\begin{tabular}{|c|c|c|c|c|c|c|}
\hline & \multicolumn{3}{|c|}{ Pyruvate, malate, glutamate } & \multicolumn{3}{|c|}{ Palmitoyl-carnitine, malate } \\
\hline & WT & KO & $\begin{array}{c}\mathrm{KO} / \mathrm{WT} \\
\text { (fold) }\end{array}$ & WT & $\mathrm{KO}$ & $\begin{array}{c}\mathrm{KO} / \mathrm{WT} \\
\text { (fold) }\end{array}$ \\
\hline Basal & $62 \pm 12$ & $147 \pm 14^{\star \star}$ & 2.37 & $94 \pm 8$ & $266 \pm 8^{\star \star \star}$ & 2.83 \\
\hline $\begin{array}{l}\text { Maximum ADP } \\
\text { stimulated } \\
\text { respiration }\end{array}$ & $397 \pm 40$ & $1478 \pm 9^{\star \star \star}$ & 3.72 & $345 \pm 13$ & $891 \pm 20^{\star * *}$ & 2.58 \\
\hline Proton leak & $55 \pm 8$ & $117 \pm 18^{*}$ & 2.14 & $58 \pm 5$ & $133 \pm 6^{* \star *}$ & 2.30 \\
\hline $\begin{array}{l}\text { Maximum } \\
\text { (FCCP) }\end{array}$ & $681 \pm 126$ & $1609 \pm 32^{* * *}$ & 2.36 & $765 \pm 68$ & $1073 \pm 45^{*}$ & 1.40 \\
\hline $\begin{array}{l}\text { Non- } \\
\text { mitochondrial }\end{array}$ & $71 \pm 8$ & $174 \pm 10^{* * *}$ & 2.45 & $77 \pm 5$ & $196 \pm 4^{* * *}$ & 2.55 \\
\hline
\end{tabular}

Rates of respiration in wildtype (WT) and VWA8 null (KO) differentiated AML12 cells Data are given as Means \pm SEM in units of pmol $\mathrm{O}_{2}$ consumption per minute. $\mathrm{N}=5$ experiments, ${ }^{*} \mathrm{P}<0.01$, ${ }^{* *} \mathrm{P}<0.001,{ }^{* *} \mathrm{P}<0.0001 \mathrm{vs}$. wildtype. Statistical analysis was done using t-tests. Pyruvate ( 5 $\mathrm{mM})$, malate $(1.0 \mathrm{mM})$, and glutamine $(10 \mathrm{mM})$ were used for carbohydrate fuel; palmitoyl-CoA $(40 \mu \mathrm{M})$, carnitine $(0.5 \mathrm{mM})$ and malate $(1.0 \mathrm{mM})$ were used for lipid fuel. Concentrations of ADP, oligomycin, FCCP, ADP and rotenone/antimycin A are given in the methods. 